\title{
Diplomatic Ceremonial as the Basis of the Culture of International Relations
}

\author{
Oksana Zakharova \\ Correspondence: Oksana Zakharova, Institute of Practical Cultural Studies and Art Management, National Academy of \\ Culture and Arts Management, 01015, 9 Lavrska Str., Kyiv, Ukraine. E-mail: o.zakharova@ nuos.pro
}

Received: December 15, 2021

Accepted: January 25, 2022

Online Published: February 4, 2022

doi:10.11114/smc.v10i1.5478

URL: https://doi.org/10.11114/smc.v10i1.5478

\begin{abstract}
Currently, there is an increased interest in the ceremonial culture in general, and in etiquette as a component of the ceremonial, in particular. This phenomenon is largely explained by their special role in the processes of communication in society, as well as a new understanding of the processes of communication and behaviour themselves. A ceremonial is a kind of cultural message from one social group of people to another. The basic idea of behaviour, the inner meaning of secular ceremonial is laid down in church rituals, and external forms of behaviour can be borrowed from the traditions of everyday secular life. The relevance of the study is determined by insufficient knowledge of diplomatic ceremonies of The Union of Soviet Socialist Republics, and the fact that knowledge of the laws of their functioning expands the understanding of domestic politics and international relations of the era, the cultural component of the life of Soviet society. The socio-cultural aspect of the topic is also relevant in scientific terms. This research can contribute to the study of the history of the organisational culture of Soviet society. Taking into account the absence of a special study devoted to the problem in historiography, the purpose of the article is to conduct a comprehensive study of the communicative functions of diplomatic ceremonial in international communication based on the analysis and generalisation of new facts with the involvement of archival materials and other sources introduced into scientific circulation for the first time. In this study, art is considered for the first time from the point of view of the communicative factor of diplomatic ceremonial. For the first time, such a term as "diplomatic counterculture" is introduced into circulation.
\end{abstract}

Keywords: etiquette, protocol, communication factor, official visit, politics

\section{Introduction}

Diplomacy as one of the spheres of applied politics is a very complex and responsible type of human activity. Diplomacy can be considered as art, as a diplomat is not only an "educated and mentally developed" person with unquestionable authority, strong will, endurance and a sense of responsibility, a diplomat is the creator of a system of international relations built on cooperation and trust, respect, sovereignty, equality, territorial integrity of the state (Wood \& Serre, 2016). To implement these principles, a necessary tool was formed - a diplomatic ceremonial, with the help of which states that differ from each other in their socio-political structure, history, culture, could build partnerships. The main functions of the ceremonial are communicative, integrative, differentiating, utopian, the function of continuity of the spiritual culture of society. The communicative function boils down to the fact that during the ceremony there is an exchange of information, which is most effective in the process of strengthening ties between states. Integration function is one of the forms of communicative behaviour (Krokhina \& Krupenin, 1997; Wood \& Serre, 2016). The presence at the ceremony contributes to the entry of an individual into a certain collective. The participation of a "novice" in the ritual is a substantial part of the integration process. It means recognition by a new participant of the main values of a social group, and as a consequence of the norms of behaviour accepted in society (Turysbek et al., 2021). Ceremonial implies pronounced hierarchical relations and this is its differentiating function.

Works of art, in their totality, make it possible to create a special "utopian" space, a kind of ideal environment for human communication, during which, with the help of certain rules of behaviour, the transfer of spiritual and moral values takes place (Motliakh, 2021; Sabadash et al., 2020). One of the main factors of the diplomatic ceremony is that visual communication technologies have been developed by man since ancient times and continue to be created at the present time. Political symbolism developed in a strict system of borrowings, which in some cases are articulated by the authorities, but for the most part require special explanations. Nonverbal communication language (sign language, 
costume, heraldry, emblems, banners, flags) in ceremonial culture serves not only for self-identification and identification of the individual, but primarily for the identification of society (Ryspayeva et al., 2021). There is a social experience in behavioural stereotypes, during communication a person realises their ethical and social affiliation. Custom is a certain order of behaviour of people in society (Krokhina \& Krupenin, 1997; Orlov, 2021). Custom develops in the process of development of social life, which, despite the diversity and complexity, is characterised by the recurrence of similar situations. In the broadest sense of the word, "customs" include forms of socio-political activity and methods of work, forms of family and marriage life, relationships in everyday life.

Custom is spontaneously transmitted actions from the collective to the individual, from one generation to another. Customs cannot include norms, the implementation of which is supported by the state. Custom is an element of the accepted way of life in society. With the development of society, there is a struggle between old and new customs. A custom that is particularly resilient and that has been preserved through the efforts of people to maintain behaviours inherited from previous generations is a tradition (Volkova et al., 2020). The tradition is characterised by attention not only to external forms of behaviour, but also to its internal content. When a form of behaviour begins to be controlled by legal acts, it becomes a ceremonial designed to maintain a harmonious connection between generations within a particular people, social group, historical community (Dalelbekkyzy et al., 2019). The ceremonial accompanies a person from the first years of their life until departure. Ceremonial is the highest stage of an organisational behavioural model based on the rules of etiquette. The next organisational model of human behaviour in society is protocol. The word "protocol", which is of Greek origin, consists of two words: "first" and "glue", which in the Middle Ages meant the first sheet glued to the manuscript, with notes on its contents (Ryspayeva et al., 2021).

Later, the word "protocol" began to be applied to the rules of conducting diplomatic affairs. One of the international concepts of this word means a document that is attached to the main text of an agreement or treaty, for example, the secret protocol to the Soviet-German treaty of 1939. The study refers to the "diplomatic protocol", which, according to the definition of the "Diplomatic Dictionary", means "a set of generally accepted rules, traditions and conventions observed by governments, foreign affairs agencies, diplomatic missions and officials in international communication" (Karyagin, 1994). Both etiquette, protocol, and ceremonial struggle with social chaos, but etiquette rather regulates interpersonal relations, while protocol and ceremonial are politics, prestige, and the image of power. Over the centuries, the diplomatic protocol has undergone significant changes, one thing has remained unchanged - embassy ceremonials are obliged to maintain the illusion of the power of the state. The so-called "no-necktie" meetings of the 90s of the XX century (that is, meetings of heads of state without observing the rules of diplomatic protocol) did not add respect to the policies of the countries that organised these ceremonies. Regarding the role of the protocol in international communication in general and during visits of heads of other states in particular, it is difficult not to agree with V.M. Sukhodrev (2008) that: "Compliance with the protocol is of great importance in diplomacy, including for establishing proper relations at the state level when it comes to visits of high statesmen and personal relations between us $<\ldots$. . Naturally, the head of state who does something wrong will not be made fun of, but he can ruin his reputation in the eyes of the hosts forever."

The purpose of the article is to conduct a comprehensive study of the communicative functions of diplomatic ceremonial in international communication based on the analysis and generalisation of new facts with the involvement of archival materials and other sources introduced into scientific circulation for the first time.

\section{Method}

In the course of the study, facts from the diplomatic ceremonies of the USSR were analyzed and summarized. The materials for the study were the files of the Foreign Policy Archive of the Russian Federation (FPA RF). With their help, a comprehensive study of the communicative functions of the diplomatic ceremonial in international communication was carried out.

The concepts of "etiquette" and "diplomatic etiquette" were analyzed in order to discover the role of art in the processes of stabilizing international communication. Various means of communication were considered. In the context of this study, attention was paid to visual means of communication, among which emblems, coats of arms, and uniforms can be distinguished. The features of various musical genres in diplomatic culture are also analyzed. A comparison of certain gestures in different cultures and their systematization were conducted in order to understand the peculiarities of kinesics in diplomatic culture. The phenomenon of dandyism was studied, and its main features were compared with the features of Soviet culture and their main differences were identified.

Since cultural processes are complex and multifaceted phenomena, there are many concepts of culture, and therefore it becomes necessary to explore the basic definitions of this concept, as well as the meaning of etiquette in various aspects of culture. Particular attention is paid to the semiotic aspect. A comparison of ritual communication and etiquette was carried out. 
The authors of the study gave a definition of the term "diplomatic counterculture" and analyzed vivid examples of its implementation. In the context of this phenomenon, the role of the protocol was also analyzed and possible positive and negative consequences of its violation were demonstrated.

\section{Results and Discussion}

\subsection{Etiquette and Ceremonial in the Communicative Aspect}

Etiquette should not be confused with the concept of "ethics". Ethics is a philosophical doctrine of morality. "Morality" in Latin means "proper behaviour". The French word e'tiquette has two meanings: "label", "tag", "inscription" and "ceremonial", "etiquette", and in turn is borrowed from the Dutch sticke ("peg") and originally meant a peg to which a piece of paper with the name of the product was attached, later - the piece of paper with the inscription itself. Currently, etiquette is understood as "a set of rules of behaviour concerning the external manifestation of attitude towards people (treatment of others, forms of addresses and greetings, behaviour in public places, manners and clothing)" (Bayburin \& Toporkov, 1990). But this definition does not take into account the differences between everyday and ceremonial behaviour. Etiquette is implemented in communication, but not all communication takes place according to the rules of etiquette. Any act of communication implies the presence of at least two partners with a communicative status. The etiquette situation is always communicative. Etiquette is a dialogue, the implementation of the rules of behaviour implies a certain response of the communication partner (Saifnazarov, 2019; Yessenbayeva et al., 2020). The tactics of behaviour largely depends on the communicative status of the partners - age, gender, national and religious affiliation, social status, family ties. Thus, etiquette initially implies inequality in communication, from which certain rules of behaviour for older and younger (age category), women and men follow in general civil etiquette.

There are two main categories in business etiquette - superior and subordinate. In diplomatic communication, interdepartmental relations also do not exclude inequality due to the official position of partners, but also in the process of establishing interstate relations, it is possible to divide into "lower" and "higher" - the ceremony of presenting credentials (in some countries, several newly arrived diplomats participate in the ceremony, the first to present the credentials is the one who has been waiting for this procedure longer). In diplomatic etiquette, as in no other, the concepts of courtesy and politeness acquire special importance, deviation from which is fraught with undesirable consequences in relations between states (Zakharova, 2015). This refers to art as a stabilising mechanism in international communication. In particular, considering it as a communicative factor of diplomatic ceremonial. It is important to note that various types of art can have a communicative status both within the ceremonial itself (architecture, music, painting) and be independent "players" in the system of international relations, contributing to the establishment of mutual understanding between the governments of various states participating in joint cultural projects or in the exchange of cultural values. One of the striking examples of the use of works of art as a communicative factor in the system of international relations is the embodiment of the image of the Imam of Chechnya and Dagestan Shamil in the works of Western European painting and literature, on the stage of the theatre.

The Caucasus keeps traces of ancient times on its land. Almost all the peoples of the Old World, moving from Asia to Europe, left settlements in the Caucasus, which, mixing with each other and local tribes, formed many types of languages. "Multilingual Caucasus", "anthill of peoples" - is how this land was called. Powerful nations of antiquity, Phoenicians, Egyptians, Greeks, Romans, Arabs, sought to establish colonies here and, having settled, spread their languages, customs, beliefs among the inhabitants. Poets and writers of ancient times praised the beauty of this land, the courage and love of freedom of its inhabitants. By the beginning of the 1940s, the Russian Empire had been conducting continuous military operations in the Caucasus for several decades. During this period, the situation in the Caucasus is escalating, where another, perhaps the most dangerous, was added to the former problems of the region - among the divided tribes who did not know one power, a leader appeared who rallied everyone under his command - Imam of Chechnya and Dagestan Shamil. After the fall of Gunib, in August 1859 Shamil was escorted to St. Petersburg. On September 15, the Imam met with the Emperor, and on September 16 he followed him to Kharkov, Shamil admired the city; he was surprised by the horse riding in the circus; he thought that a circus performance was magic. "When they took him to the ball, and he saw the brilliant costumes of the ladies, he jumped back a few steps and began to pray. $<\ldots>$ He was also amazed by the lighting and decoration of the hall. The crowd followed the Caucasian Lion" (Chichagov, 1999). While in Moscow, Shamil met with A.P. Ermolov, toured the Kremlin Palace and other sights of the first capital; he visited the theatre where the ballet Nayada was performed.

In St. Petersburg, he was shown St. Isaac's Cathedral, leaving which with the archpriest, he bowed his head and put his hand to his heart. Shamil inspected the Public Library and the "Kunstkammer", he was taken to the Italian opera, to the ballets "Katarina" and "Peri". He also visited the photo of Alexandrovsky, where portraits were taken from him. Shamil amazed everyone with his sociability, the extraordinary tact with which he treated his position. The formidable ruler of Dagestan surprised with his refined worldliness and courtesy. The leader of the highlanders of the North Caucasus 
belongs to those figures who cannot leave artists, poets, writers, composers indifferent. The pictures of Shamil by such famous masters of the brush as Franz Roubaud, T. Horschelt, E. Lanceray, G. Gagarin, V. Vereshchagin, N. Sverchkov, V. Timm and others have survived. Shamil's story also excited foreign artists who created portraits of the Imam, guided only by imagination (Donogono-Korkmas, 1990). On July 26, 1854, French playwright P. Meris' five-act play "Shamil" premiered at the Sainte-Martin Theatre in Paris. The music was composed by the composer M. Gondue and the main role was played by M. Melinge. The time of action in the play is April-October 1834, that is, the year of Shamil's election as Imam. One of the Russian artists who embodied the image of Shamil in painting was Prince Gagarin, who in 1853, with the support of the Caucasian viceroy M.S. Vorontsov, painted the Zion Cathedral of the Exarchs of Georgia, the beginning of the construction of which dates back to the reign of V. Gorgasal (V century), and the end to the first half of the VII century. The temple that kept the greatest shrine of Georgia - the Holy Cross Nina, made of two pieces of vine and intertwined with the hair of the educator of Georgia, was repeatedly destroyed.

Prince Gagarin, who became vice-president of the Academy of Arts in 1859 (in office until 1872), was once impressed by the grandeur of Byzantine art and travelled throughout Europe and Asia to Turkey and Italy in search of its samples. He paints the Zion Cathedral in the Byzantine style, using for the first time in Russia the so-called encaustic method of fresco painting - the paints are prepared from a special mastic-wax essence. The Prince drew up plans for churches in the Caucasus: in Khasavyurt, Derbent, Kutaisi, Grozny, Tiflis (military cathedral and gymnasium church), Borjomi and other places of the region. Thus, the personality of Shamil, embodied in the works of Western European art, has become a kind of communicative factor in the relations of European states with the Russian Empire. At the same time, the Imam of Chechnya and Dagestan demonstrates not only religious tolerance, but also respect for the works of modern European culture, visits the library, theatre, military review and ball. Thus, Shamil, as the leader of the state he created, enters into a dialogue with Europe, while demonstrating loyalty to his religious and moral values that determine the purpose and nature of cultural communications. The means of communication have been created by man since ancient times and continue to be developed at the present time. In addition to languages and their dialects, there are means of visual self-identification and identification, which serve to store and transmit information.

One of the visual means of communication includes heraldic signs in the broadest sense of this concept - emblems, coats of arms, uniform, which have been known since ancient times, when there was a need not only for self-identification of the individual, but also for the identification of society. But at the same time, heraldic signs can act not only as a communicative factor, but also directly as a communicative object. So state and military ceremonies include such an important component as flag etiquette. In diplomatic culture, a special role is also given to the etiquette of the anthem, in the performance of which certain rules of conduct should be followed. It should be noted that different musical genres allow mutually exclusive norms of behaviour. For example, whistling is unacceptable in the conservatory hall, "booing" the performer means expressing rejection, condemnation of their work. At the same time, whistling at a rock concert is a sign of approval, a kind of audio applause. Gestures, facial expressions, poses make up an important section of etiquette, which is studied within the framework of a special subdiscipline - kinesics. The kinesic means also include the manner of dressing, the features of using things. Gestures occupy one of the main places among the kinesic means of communication. Only those movements that have a symbolic character have the status of a gesture, when they are attributed not only practical, but also symbolic meaning. The movement should also have a communicative orientation (Bayburin \& Toporkov, 1990). In business etiquette, the greeting is followed by a handshake - the outstretched hand is turned to another person.

At any ceremonial, a person's behaviour is a series of consecutive gestures, each of which has a symbolic meaning. At the same time, it should be noted that within the framework of the European business behavioural culture, the same gesture can have two interpretations. For example, nodding forward almost everywhere means "yes", and shaking your head from side to side means "no". But in some countries, including Bulgaria, it is the opposite. The circle formed by the index and thumb of a person's hand is "OK" ("good"). But in France this gesture means "zero" or "nothing", and in some Mediterranean countries (in Greece and others) it refers to homosexuals. Thus, in the process of any communication, gestures require careful handling. The look is also one of the important elements of communication. Experts in the field of ethnography divide human cultures into "contact" and "non-contact". Of great importance in communication is the view in "contact cultures", which include Spaniards, Italians, Portuguese, Latin Americans, Arabs. The "non-contact" cultures include the peoples inhabiting the north of Europe, Indians, Japanese, Pakistanis (Zakharova, 2015; Sukhonos et al., 2021). Among the Slavs, it is customary to look at the interlocutor and at the same time, it is forbidden to stare at a stranger. The communicative functions of the costume, as one of the components of the nonverbal language of communication, manifested themselves in the greatest way in the era of dandyism. The original appearance testified to the original thinking. However, a dandy is not a walking tailcoat, only a special way of wearing it. It is possible to remain a dandy in rumpled clothes, but with a sense of innate nobility. Dandyism is a lifestyle based on a challenge, opposition to the ruling elite. The very idea of a career was hateful to the dandy. 
Dandyism manifested itself especially vividly in the imperial states, where there was a regulation of fashion by legal acts and, as a consequence- the concept of uniforms. The uniform meant a place of service, belonging to a certain social circle. In the army, and especially in the Guard, the concept of the honour of the uniform is inextricably linked to the concepts of "regimental honour" and "personal honour". In turn, the key concept of the Guard officer's worldview is honour, a moral responsibility to the ancestors for their actions and deeds. Thus, the value system influenced not only the internal, but also the external properties of a person, in the aggregate of which they act as a partner in the process of etiquette communication. For many officers, the fascination with new political ideas began with the imitation of external forms. Refusal to participate in dancing, extravagant costume, defiant manners were iconic symbols of the 19th and early 20th century opposition. In the Soviet period, the struggle with the European ceremonial costume - evening dress, tuxedo, tailcoat, as well as European dances (foxtrot, tango) - is a struggle with bourgeois values, which were reflected, among other things, in the European rules of good manners. "Appearance, i.e. clothing, food, housing, all these are parts of the silent language of culture, which speaks the more eloquently the more sharply it contradicts the surrounding appearance. To win the right to such an open contradiction means to clear the way for a new idea, a new social fact, to overcome an important obstacle for its entry into life," wrote P.N. Milyukov (1993). The rivalry in the introduction to a new lifestyle was a kind of parochialism, in which, however, not the most well-born won.

Cultural processes are complex and multifaceted phenomena, and they can be investigated by different methods. Therefore, at present there are many concepts of culture, each of which explains and systematises cultural processes in its own way. With the help of the term culture, it is possible to characterise a particular era, a particular people, a particular sphere of life. One of the definitions of "culture" of the philosophical type is the point of view that culture is the expression of society in the forms of literature, art or thinking. "The role structure of the communicative situation in traditional culture has a certain specificity. Firstly, a person always behaves taking into account the fact that some higher forces are watching them, and both the ritual and the etiquette situation can be organised in such a way as to ensure the direct participation of these forces. In a number of cases, one of the partners acts on behalf of God, deceased relatives, masters of another world, etc. Accordingly, the verbal and behavioural texts that they generate seem to come not from them personally, but from those higher forces, whose representative they are" (Bayburin \& Toporkov, 1990). In the semiotic aspect, etiquette is a certain system of signs, its own dictionary - a set of symbols and grammar - rules for combining signs and constructing texts.

But unlike rituals, etiquette has a pronounced situational character, the specifics of the situation dictate the choice of communication signs. Participants in ritual communication behave in accordance with their social status. During the ritual, the individual is first and foremost a representative of a class, a social group; their social position dictates the language of ritual behaviour on the part of their communicative partners in communication. Violation of these rules is a challenge to public morality, undermining the moral foundations of the community, which in turn creates a critical revolutionary situation. If there is a change in the form of government in the state, then the new authorities begin to introduce new rituals. The Great French Revolution contributed to the "transformation of morals". At that time, the old norms of relationships between people were being eradicated. A citizen was allowed to take off their headdress only when making a public speech or when it was hot. The letters should not have been signed by "Your most humble, most obedient servant", but "your fellow citizen, brother, friend, comrade". Instead of referring to "vous" (formal "you") the decree of November 8, 1793 introduced an appeal to "tu" (informal). Deputy Chalier introduced a draft decree to the Convent on republican forms of politeness, dress and customs. "Republican politeness", the draft said - "politeness of nature itself!" This contrasted with the refined and conventional politeness of the aristocracy. Chalier opposed the "exaggerated, artificial, prim politeness, aristocratic elegance and ceremonial, which were cultivated by tyrants in order to impress and dominate" (Krokhina \& Krupenin, 1997).

Etiquette determines the external forms of behaviour and treatment of other people - intonation, tone, expression of speech, style of cut and costume decoration. The totality of all these properties is called manners. The attitude towards them varies among different social groups. For an aristocrat, noble behaviour means belonging to the "upper world", it is a sign of an exceptional position in society in the 18th and 19th centuries. The enlighteners of the 18th century considered etiquette as a means of power. It united the European nobility as the main social support of the monarchical power. Among the European nobility of the XVIII - early XX century, there was a lifestyle that was actually called "etiquette". Etiquette as a way of existence of the court public and European monarchs. Simultaneously with the development and strengthening of the power of the third estate, the bourgeoisie, etiquette begins to adapt to the changed social conditions. It ceases to be the privilege of aristocrats, who, while retaining their nobility, lose their former wealth and power. The bourgeoisie strives to imitate the noble class in the lifestyle, while external forms prevail over the content. It is only in the twentieth century that the democratisation of etiquette takes place. The lifestyle itself is becoming more and more universal. A person appears in society:

- as a participant in the economic process; 
- as a participant in the political process;

- as a member of a certain professional community;

- as well as a tourist (Chopin, 2018).

European etiquette has lost its class character. Fundamentally new forms of etiquette have been developed, based on: professional characteristics; on the uniqueness of certain life situations; on the specificity of some spheres of life of modern society. Human beings are social creatures; communication is an important part of life. Communication can be "literate" or "illiterate". Communication can be a wall that divides people or, conversely, "the only real luxury", as Antoine de Saint-Exupéry noted (Crow, 2018). Both ritual and etiquette struggle with social chaos, but etiquette at the same time should provide a comfortable aesthetic environment for partners in communication, ritual is an expression of the basic moral concepts of society. There is a constant and mutual enrichment of etiquette and ritual communication, the study of the latter can help in understanding the true meaning of the origins of modern rules of behaviour. In order to build effective and competent relationships with people in the process of professional activity, the manager needs to have a certain culture of communication. State and military ceremonials are the means of organisational culture, its reproduction in the conditions of generational change of managers and ordinary employees (Kutsyi, 2021).

The term "organisational culture" covers a large area of phenomena of the spiritual and material life of the collective: its moral norms and values; code of conduct and ingrained rituals, dress manners. The adaptation of employees to the collective is the entry into the organisational culture, its norms, traditions, it is the adjustment of the individual to the requirements of the social structure, which has a certain educational effect (Serdali et al., 2017). The management philosophy sets the appropriate culture of intra-organisational relations. At the same time, special attention should be paid to "creating and maintaining positive (socially and psychologically) traditions in the team", these can be ceremonies for the reception of new employees, seeing off veterans, organising anniversaries and charity events. In this case, one of the main goals of the ceremony is to foster a sense of pride in the organisation, respect for it and colleagues (Krichevsky, 1998). The rules of conduct of military and diplomatic ceremonies are painted to the smallest detail. But if a military parade as the highest form of military art is addressed not only to military personnel, but to various segments of the population, then a diplomatic ceremony, for example, the ceremony of presenting credentials, is of an elite nature.

\subsection{Diplomatic Counterculture as an Element of a Diplomatic Institution}

The protocol makes it possible to establish friendly relations with some individuals and at the same time avoid conflict with others. Local traditions should be respected and, if necessary, accepted rules should be changed by explaining the reason for the change in advance. The personal feelings of the communication participants can also influence the development of the protocol. "The Turkish Sultan did not want to recognise the partition of Poland between Russia, Austria and Prussia. Therefore, at receptions with the participation of the diplomatic corps, at which the ambassadors had to alternately approach the Sultan and greet him, when the turn came to the Polish ambassador and no one came (although he was present), the chamberlain turned to the Sultan and said: "The ambassador went for a walk and was held up due to the snowfall". This statement was made regardless of the time of year" (Wood \& Serre, 2016). Deliberate violation of etiquette is a calculated demonstration of distrust of the diplomat and, as a consequence, of the state represented by them. But at the same time, there is an opinion that women are more "sensitive" to such insults than men, who readily accept explanations. "However, not many are able to respond as Count B. de Castellane replied to the hostess, who apologised to him for not being able to provide him with a seat in accordance with his position: "Madam, my seat is always the best" " (Wood \& Serre, 2016). Violation of the protocol can occur either out of ignorance, which happens quite rarely among professional politicians, or for the purpose of public demonstration of rejection of certain political goals.

Diplomatic counterculture refers to the deliberate disregard by heads of state, government, foreign agencies, public and political figures, diplomats and their family members, employees of embassies and international organisations of generally accepted protocol norms, traditions and conventions, as well as the rules of respect and politeness generally accepted in international practice, observed in diplomatic, official and interpersonal relations in order to influence foreign policy decisions of participants in international communication. One of the important features of diplomatic etiquette is the principle of hospitality, which, in particular, is manifested in the ceremony of exchanging gifts. At the same time, the gift itself acts as an element of diplomatic communication, which has certain functions. In this regard, works of art have a special role. Not only the creations of a painter, a sculptor, a master of decorative and applied arts can act as a gift, but also: an invitation to a performance, a concert, an excursion, a sports competition. At the same time, participants in communication must comply with both the rules of etiquette behaviour adopted in such cases and the norms of diplomatic protocol. For example, standing up during the national anthem. In this respect, very indicative is the meeting on February 1, 1935 of the Polish Charge d'affaires with a representative of the People's Commissariat for Foreign Affairs (NKID), who demanded from the Polish diplomat an explanation of the behaviour of some members of 
the diplomatic corps, who during one of the official events sat during the "singing of our anthem" (FPA RF. F. 057. Op. 15. P. 112. D 2).

The diplomat responded by saying that he thought "it was not the anthem being played, but the Soviet party song being sung". The words of the "Internationale", in his opinion, do not have the character of an anthem but a song of revolutionary workers calling for the overthrow of the bourgeoisie. Therefore, he considered musical performance to be an anthem and always stood up on solemn occasions. In this situation, it was not about singing the anthem when Kalinin appeared as the head of state, but about singing the "International" in honour of I.V. Stalin, as the leader of the proletariat. In turn, the Polish diplomat also noted that the Union of Soviet Socialist Republics (USSR) has not developed an appropriate "protocol ceremonial" that would determine in which cases diplomats should stand up, especially abroad he has heard the singing of the "Internationale" in different languages many times and everyone understood that this is a revolutionary song. The Soviets continued to insist that no rules were required in these situations, just as it was clear to everyone that they had to stand up when the anthem was played. As a result of this conversation, the NCID decided not to make representations to the relevant embassies (about half of the diplomats, including representatives of Germany and Japan, did not stand up during the performance of the "Internationale", to which special attention is paid in the report), hoping that they themselves would understand "the impropriety of their behaviour" (FPA RF. F. 057. Op. 15. P. 112. D. 2).

It should be noted that from the point of view of diplomatic courtesy, diplomats accredited in Moscow were not obliged to pay official attention to I.V. Stalin, since he did not hold, as the Iranian ambassador noted, "any official leadership post in the system of the Soviet state," therefore, without receiving instructions from the doyen of the diplomatic corps, he did not congratulate I.V. Stalin on his 60th birthday. For the same reason, namely that Stalin is not officially head of state, the Danish and Norwegian envoys did not congratulate I.V. Stalin. But the latter noted at the same time that he was "filled with sincere feelings of respect and admiration for Mr Stalin" (FPA RF. F. 057. Op. 19. P. 113. D. 1). Among Soviet politicians, one of the most sophisticated improvisers who professionally manipulated the norms of diplomatic protocol and etiquette was I.V. Stalin. In August 1939, after negotiations with I. Ribbentrop, during a dinner he toasted Hitler as a man deeply respected by him, and at the end of the reception allowed the Führer's personal photographer to take several pictures (foreigners were forbidden to photograph in the Kremlin), in which I.V. Stalin and the guests were depicted with glasses of Crimean champagne in their hands. In 1939, I. Ribbentrop speaks of the leader as a man of extraordinary scale. I.V. Stalin managed to literally stun the German Foreign Minister, and in August 1942, the Prime Minister of Great Britain.

W. Churchill (2020) notes the hospitality of I.V. Stalin at a dinner in the Kremlin and offers a toast to his health. At the end of the reception, after an official farewell handshake with I.V. Stalin, W. Churchill headed for the exit, but the leader caught up with him and escorted him to the front door, where they shook hands again. Stalin's invitation of W. Churchill to his apartment in the Kremlin also goes beyond the official protocol norms. I.V. Stalin made a mistake by not inviting his daughter to the table, as W. Churchill informs the President of the United States of America (USA) F.D. Roosevelt. Stalin's feasts are "men's gatherings", but the leader invited a gentleman to his house, for whom the attitude towards a woman is a measure of morality in a person. In this case, I.V. Stalin "did not play out" to the end the role of a strict but loving "father of all peoples". The protocol is conservative. A protocol rule that honours the application of one person once cannot be omitted in respect of another. "Any precedent for the protocol is fraught with the fact that it should become the norm, and if the norms are cancelled, then this is also a precedent that creates a new norm; this is the ABC of every aspiring diplomat" (Karyagin, 1994). In the USSR, until January 1, 1944, the national anthem was the "Internationale", therefore, when the first Soviet ambassador arrived in Finland, it was decided to cancel forever the performance of the national anthem of the country of the arriving diplomat before presenting his credentials.

There have been cases where precedents did not become the norm. In April 1941, the Soviet-Japanese neutrality pact was signed in Moscow. I.V. Stalin personally came to the railway station to see off the Japanese minister. This did not become the norm in Soviet protocol, but its political significance was considerable. Stalin paid tribute to the importance of the protocol in international relations, personally delving into all the details of diplomatic events, including the preparation of the Yalta and Potsdam Conferences. The leader also took an active part in resolving diplomatic scandals. In 1951, covert listening devices were discovered at the Australian Embassy in Moscow. I.V. Stalin personally dealt with such issues. The initial draft of the response provoked his criticism. "In a transformed form, the Soviet response even appealed to sympathy. It said that there was a brutal war and it was possible that Moscow would have to be abandoned. In these circumstances, in a number of buildings that could presumably be occupied by the highest German command, covert recording equipment was installed, which, after the war, were apparently forgotten to be dismantled ... " After reviewing this sample of "diplomatic hypocrisy," the Australian Foreign Minister said that "this is a pure lie, but...it's not a bad one" (Karyagin, 1994). The incident was settled. In the 50s - early 60s, actively fighting for "new" friends, the Soviet Union did not forget the "old" actors of world politics - the United Kingdom and the United States. 
In February 1959, the USSR was visited by the British Prime Minister H. Macmillan, who considered his visit as a response to Khrushchev's visit to England in 1956, the purpose of the visit was to exchange views with the leadership of the USSR on international issues. The program of the stay included negotiations, excursions, cultural and representative events, trips around the country. But due to the complications of the negotiation process, the program began to change in the direction of reducing its entertainment part and expanding the negotiation process. The first hunt was canceled, at which the guest had to be dressed in a protective fur jumpsuit and dog fur boots. A Tula rifle with gold notches and mother-of-pearl inlay was prepared as a gift. Then followed the events that are directly related to the concept of "diplomatic counterculture". Before travelling around the country, at a reception at the British embassy on February 24, N.S. Khrushchev announced that he was going to Kyiv with a guest tomorrow, but instead of that the next day $\mathrm{Mr}$ Macmillan, accompanied by Foreign Minister S. Lloyd and Ambassador Sir P. Riley, went to Khrushchev's dacha, where there were (except for members of the family of the Soviet leader) A.I. Mikoyan, A.A. Gromyko and the Soviet ambassador in London Ya.A. Malik. The next morning, in the same composition, a conversation took place in the Kremlin, after which Mr Macmillan left for the airfield, where he learned that First Deputy Minister of Foreign Affairs V.V. Kuznetsov had been appointed senior accompanying person. The Prime Minister delayed landing, constantly talking to the companions, but then the members of the delegation boarded the plane.

In Kyiv, all members of the British delegation pretended that nothing had happened. At an official dinner, H. Macmillan even exchanged "elegant compliments" with the Chairman of the Council of Ministers of the Ukrainian Soviet Socialist Republic (Ukrainian SSR) N.T. Kalchenko, saying in his toast that he was "flattered to be the guest of the Prime Minister, who was a general during the war, while he himself, G. Macmillan, only rose to the rank of captain during the First World War." N.T. Kalchenko gave an answer in no less elegant form, noting that it gives him pleasure "to receive a former infantry captain who has now become the captain of such a large ship" (Karyagin, 1994). In the capital of Ukraine, the guests visited the Opera and Ballet Theater, a dinner was given in honour of the English delegation at the Mariinsky Palace. At the agricultural exhibition, the guests were greatly impressed by its organisation and design. S. Lloyd noted that it was the first time he saw an exhibition of such a high level. Mr. McMillan's personal secretary said that if the Conservative Party had organised such an exhibition before the election, it would have won there. At the dinner, the Prime Minister expressed admiration for the restoration work in Kyiv and in the republic, noted the role of N.S. Khrushchev in this, mentioned that the British participated in the construction of Europe's largest Dnepropetrovsk tire plant. "If peace is indivisible," Mr Macmillan said, then mutual prosperity is also indivisible $<\ldots>$. It is not enough to wish for peace and talk about it, we must work hard to achieve it $<\ldots>$ by overcoming difficulties and misunderstandings" (FPA RF. F. 57. Op. 46. P. 279. D. 52).

An aide to Prime Minister Zulueta said in an interview with a Soviet representative: "Dulles is ill, Adenauer is furious, and de Gaulle behaves like an absolute king $<\ldots>$ Mr Macmillan remains the only working and thinking figure of the West, but he cannot take responsibility for having the last word with the Soviet side." Evans, the Prime minister's press secretary, stated in one of the conversations with the Soviet representative that "England is used to listening to everyone, but doing as it needs to do, and that Mr Macmillan will be in the USSR as long as the programme provides" (FPA RF. F. 57. Op. 46. P. 279. D. 52). The visit to Kyiv made a strong impression on the British guests. Everything from the ballet " The Forest Song" and to the Exhibition of Achievements of the National Economy, was highly commended. The protocol "misunderstanding" was smoothed out in Leningrad, where H. Macmillan was met not by the chairman of the Leningrad City Executive Committee, as was indicated in the program, but by A.I. Mikoyan and A.A. Gromyko, who unexpectedly arrived in Leningrad to accompany the Prime Minister here. Khrushchev's protocol demonstration was unpleasant to Mr Macmillan and it is difficult to imagine that he forgot about it afterwards. One of the main qualities of a gentleman is constant self-control. The ability to control oneself, to respect the human personality is taught in England since childhood.

In 1954, a meeting of the foreign ministers of the four powers was held in West Berlin. When the break was announced, and the Soviet delegation headed for the exit. High Commissioner V.S. Semenov returned V.V. Karyagin (1994) "for some little thing" left on the table. Fearing that the delegation would leave without him, V.V. Karyagin (1994) rushed down the stairs "barely touching the steps with the tips of his heels". When a few steps remained to the landing of the lower floor, a group of people appeared from the corridor. "Barely having time to "slow down", I found myself in the middle of this group and, with my foot brought up for the next jump, stepped on someone's shoe. A man in a dark blue striped suit, without showing any emotion, calmly bent down and began to adjust his shoes. In response to my apologies, one of his companions made an equally imperturbable gesture, which meant that I could continue on my way, and only then did I recognise the English Minister (Prime Minister A. Eden - auth.) in the bent man" (Karyagin, 1994). Another example of English composure and "gentlemanly restraint" was the behaviour of Prime Minister H. Macmillan in 1960 during the 15th session of the United Nations General Assembly (UN), at which Soviet leader N.S. Khrushchev, communicating with opponents, used the methods of "shoe diplomacy". The events related to the reconnaissance flight 
of the U-2 aircraft shot down near Sverdlovsk on May 1, 1960, finally soured relations between the United States and the USSR.

In 1960, N.S. Khrushchev decided to personally lead the Soviet delegation that went to New York to participate in the work of the UN General Assembly. Arriving in New York, N.S. Khrushchev decided that, as at Soviet party congresses, he should attend all sessions, while according to established tradition, heads of state and government appear in the meeting room only on the day of their speech. Even the Minister of Foreign Affairs of the USSR A.A. Gromyko failed to dissuade N.S. Khrushchev. N.S. Khrushchev rushed to the podium during the meetings in order to "open everyone's eyes to what is happening in the world." Finally, he was given the floor, the speech of the Soviet leader lasted more than 2 hours. In it, in particular, proposals were made to eliminate colonialism, to establish a "troika" instead of the post of one UN Secretary-General. During N.S. Khrushchev's speech, he took a glass of Borjomi, sipped from it and advised everyone present to try it. During the general discussion, many speakers said that in addition to colonialism, there is another kind of oppression, namely, the political system imposed by the USSR on the countries of Eastern Europe. N.S. Khrushchev hardly restrained his emotions. After the words of one of the speakers about the "bloody actions of the Soviet Union" in Hungary in 1956, the leader of the Soviet state began to object loudly to the speakers from the spot. Microphones were not installed in front of delegates at that time. N.S. Khrushchev shouted, but the interpreters did not hear him. The Prime Minister of England, H. Macmillan, when N.S. Khrushchev began to shout something again, interrupted his speech and said: "If only someone would translate it for me, or something..." (Sukhodrev, 2008).

The next day, statements continued to be made from the UN rostrum, which N.S. Khrushchev perceived as attacks against communism, the Soviet Union and the socialist system as a whole. Protesting, he continued to bang his fists on the table. At some point he took off his boot and started banging it. The famous Soviet translator V.M. Sukhodrev (2008), who was in the UN meeting room that day, notes in his memoirs that "it was not really a boot, although it was later called that in all the newspapers of the world, but rather something like a sandal, with several straps on the toe. Khrushchev then liked to wear blunt-nosed brown shoes in warm weather. When he started pounding the table with his shoe, I felt sick. I don't think I was the only one." V.M. Sukhodrev (2008) was right, in his memoirs N.S. Khrushchev writes that Nehru did not really approve of this act. Although, the apotheosis of the scandal on this day was the speech of N.S. Khrushchev, in which he shouted about the overthrow of the "bloody regime" of Franco by the people of Spain. According to the laws of parliamentarism, this is a clear insult. Franco was the head of a UN member state. The chairman of the session unsuccessfully tried to deprive N.S. Khrushchev of the word, but Khrushchev did not have headphones through which simultaneous interpretation was received and he did not understand Boland's English speech.

V.M. Sukhodrev (2008), who was in the UN Meeting Room that day, gives the following description of the events that followed: "Guessing that the chairman was trying to reason with him, he (N.S. Khrushchev - auth.) turned to him and began to denounce Boland:

- Oh, is that so?! And you too, chairman, support this vile lackey of imperialism and fascism?! Let me tell you: the time will come and the people of Ireland will overthrow such servants of imperialism as you are!

The Irish are an emotional and hot-headed people. Boland, hearing attacks now directed at him, turned crimson and shouted:

- You are breaking all the rules! I deprive you of the word and close the meeting!".

After these words, Boland hit the wooden stand hard with the chairman's hammer. The hammer cracked, its head flew into the hall. N.S. Khrushchev continued to shout, but no one heard him, because the microphone was turned off. After Boland left the hall, N.S. Khrushchev returned to his seat. The hammer head became a museum exhibit in a building on the East River. The Norwegians presented the chairman with a new hammer made of black wood and covered with Viking ornaments. The protocol often demonstrates the nature of relations between states. V.V. Karyagin (1994) recalled that as Deputy Head of Protocol Affairs of the Ministry of Foreign Affairs (MFA) of the USSR in 1963, he was delegated to meet W. Averell Harriman, who held the position of Deputy Secretary of State at that time. W. Averell Harriman was the American ambassador to the USSR during the war and, as an ambassador-at-large responsible, carried out important assignments for F.D. Roosevelt in various parts of the world. W. Averell Harriman enjoyed well-deserved respect in Moscow, and apparently, that is why he was entrusted with the mission to enter into negotiations on the south-eastern settlement. But the Soviet side was clearly not satisfied with the development of events. Apparently, this was the main reason for the protocol demonstration, when instead of the Deputy Minister of Foreign Affairs, W. Averell Harriman met by the Deputy Head of the Protocol Department. On the day of arrival, the American Ambassador Foy D. Kohler boarded the plane and warned the guest about the current situation. "Harriman came down the ramp with a smile and even at the request of American reporters invited me to take a picture," recalled V.V. Karyagin (1994).

The New York Times reported that the deputy secretary of state was met by the deputy head of the Protocol Department 
of the USSR Foreign Ministry, although "by rank" the deputy foreign secretary or the head of the American department should have met him. The demonstration was noticed. On May 22, 1972, at four o'clock Moscow time, the first official visit of the US president to the Soviet Union began. At the ramp of the plane Richard Nixon was met by Podgorny and A.P. Kosygin, members of the government, employees of the US Embassy, a small group of "workers". The "enthusiastic" crowds of Muscovites were also absent along the route of the presidential motorcade to the Kremlin. The reason was the Vietnam War. Thus, the norms of the protocol continued to depend on the foreign policy situation. The residence of R. Nixon was located in the Kremlin, over which the US flag was waving for the first time. In the negotiations in the Catherine Hall of the Grand Kremlin Palace, the topic of Vietnam could not be avoided, but the main problem was the discussion of the issue of limiting strategic weapons. On one of the days of the visit, Richard Nixon was to speak live in front of the viewers. The President asked V.M. Sukhodrev (2008) to be the one to read the translation of his speech behind the scenes. The professionalism of V.M. Sukhodrev (2008) was known far beyond the borders of the Fatherland.

The preparation of the translation was not without its problems. "The fact is that at that time the American propaganda service recommended that the Voice of America radio station broadcasting in Russian not use the phrase "Soviet people" on the air. They claimed it is to say "people living in the USSR"." The hint was clear - the peoples of the republics of the USSR do not voluntarily live as part of the Soviet state. Thus, Richard Nixon inserted the phrase "people living in the Soviet Union" into the text of his televised address. "Without getting into high politics, I began to convince my American colleagues that in Russian this phrase sounds clumsy, awkward, and unusual. It is better then to use the phrase "Soviet people". But the Americans did not agree. An argument broke out. In the end, I had to turn to one of the high officials of the State Department, and he resolved the issue in my favour," recalled V.M. Sukhodrev (2008). The speech was broadcast live from the Kremlin's Green Living Room. Richard Nixon spoke with emotion about the hardships that Soviet people endured during the war. When the president, "shocked by the impression of visiting the Piskarevsky Memorial Complex in Leningrad, recalled the famous diary of schoolgirl T. Savicheva and quoted a few phrases from it, I felt my throat tightened" (Sukhodrev, 2008).

The next day V.M. Sukhodrev (2008) was praised for his work by the country's chief security officer A.N. Shelepin, known for his toughness. From Moscow, the American delegation, headed by the president, flew to Kyiv. Shortly before landing, Richard Nixon invited V.M. Sukhodrev to his cabin. The President decided to consult with V.M. Sukhodrev should he speak in his speech about Kyiv as "the mother of Russian cities", will this not cause confusion among the people of Kyiv? V.M. Sukhodrev assured the president that there should be no such reaction, since this expression reflects historical reality. In Kiev, a city tour, laying a wreath at the Grave of the Unknown Soldier and a solemn banquet took place. At the reception, V.M. Sukhodrev (2008), in a conversation with one of the local leaders, suggested that the toast would be delivered in his native language, but the latter waved his hands in despair: "No way! Never! We will be accused of nationalism... Only in Russian!". In most of the programmes of visits from other countries to the USSR, a visit to Ukraine was given a special place, which is especially noticeable in the post-war years. The intellectual potential of Ukraine allowed the republic, despite the Holodomor, repressions, losses during the Second World War, to be one of the most developed not only economically, but also culturally.

Hospitality is an important component of national policy. The protocol department with its work tried to destroy stereotypes about the USSR as an evil empire. The multinational Soviet culture contributed to the creation of a positive image of the state on the world stage. Since about the mid-1960s, the records of the Protocol Department (in most cases) lack information that conveys the atmosphere, a "mood" of the visit. The necessary information can be found in sources of personal origin. Thus, the memoirs of V.M. Sukhodrev (2008) contain interesting details of the visit to the USSR of Canadian Prime Minister P. Trudeau, whose name is associated with the period of warming and the development of friendly relations between the two countries. In 1971, P. Trudeau visited the Soviet Union. P. Trudeau impressed everyone not only with his style of behaviour, he rode one of the escort motorcycles on the territory of the Kremlin, but also with his appearance - trendy wide bright ties, jackets with huge lapels, platform shoes and flared trousers. One can argue about how much such an appearance corresponds to the atmosphere of official receptions, but it is obvious that it is appropriate at the disco, where P. Trudeau and his wife wanted to go in Kyiv. The Prime Minister of Canada could not but visit Ukraine, whose immigrants live in significant numbers in Canada and in some parts of the country can have a serious impact on the election results.

P. Trudeau's desire to visit a disco or a nightclub without official escorts was conveyed by V.M. Sukhodrev (2008) to the head of security, who asked for 15-20 minutes to prepare. A disco for the Prime Minister was organised on Khreshchatyk, not far from the residence, the Trudeau couple went there on foot (there were guards, but they tried to be inconspicuous). "Nobody paid attention to P. Trudeau. No one could have imagined that this fashionably dressed fellow with sideburns, walking in an embrace with a thin, long-haired girl (Trudeau had married shortly before his visit author) - Prime Minister of Canada." At the club, P. Trudeau was led to a table set for two. And a "chic imitation" of the 
life of a nightclub began: the "guests" danced, the lights were turned down. P. Trudeau and his wife drank champagne and went dancing. According to V.M. Sukhodrev (2008), who was at the disco, the Canadian couple danced "very briskly and incendiary." P. Trudeau's visit was remembered not only for his vivid travels around the country. Important agreements were signed and a joint statement was adopted. One of the members of the Politburo even proposed to establish in the USSR the production of fabrics of fashionable bright colours, but his impulse caused a very predictable reaction: "No, we don't need it. Let P. Trudeau wear such ties himself...". A.P. Kosygin and P. Trudeau established good relations after his visit to the USSR, they, according to V.M. Sukhodrev (2008), enjoyed each other's company. Behind the seemingly "dry" language of the protocol are specific personalities with their usual characters. In some cases, violation of protocol norms not only does not interfere with solving the tasks set, but even contributes to their implementation.

In the 70s - early 80s, the activities of the employees of the Protocol Department of the USSR Ministry of Foreign Affairs, as in previous years, were highly appreciated by guests from other countries. So, in 1972, at the end of the visit to the USSR of the Assistant to the US President for National Security Affairs H. Kissinger, a message was sent from the US Embassy to the head of the US Department of the USSR Ministry of Foreign Affairs G.M. Kornienko, in which it was reported that, according to the American side, none of the other visits of $\mathrm{H}$. Kissinger "was ever so well provided for". Protocol and other events at the airfield, transportation services, accommodation at the residence on Lenin Hills, as well as security measures were organised in the best possible way. "We highly appreciate your concern for the crew of the aircraft, who visited the ballet, the circus and the Exhibition of Achievements of the National Economy," the message said. The American side asked to convey gratitude to all the employees who carried out the visit for showing "the highest degree of hospitality and co-operation" (FPA RF. F. 57. Op. 78. P. 623. D. 14). French diplomats often "gave lessons" of the classical diplomatic protocol to their colleagues from other countries. In 1963, the French bank holiday, July 14, fell on a Sunday, and the Soviet side proposed to postpone the reception to another day of the week in order to ensure high representation from the Soviet side, since many of the invitees would be out of town. French Ambassador M. Dejean was categorical: "France celebrates its holiday on July 14, and it is not possible to postpone it to another day, but he, the ambassador, will not be offended if circumstances do not allow any of the Soviet invitees to attend the reception. The level of representation at the reception was high" (Karyagin, 1994).

Pope Paul VI was a man who boldly broke the usual stereotypes. "His papacy was marked by the fact that he ended the century-long seclusion of popes that had been going on since 1870, visited many countries, advocating for peace and peaceful existence." The secular views of the Pope are evidenced by the story told by the American diplomat J. Wood. During Jacqueline Kennedy's visit to the Vatican, the Papal Court was offered a choice of three options for addressing the President's wife: "Madam President's wife", "Mrs Kennedy", or "Madam". But when Jacqueline Kennedy came to the audience, the Pope stretched out his arms to her and exclaimed: "Oh, Jacqueline!" The violation of protocol norms was made not with the aim of offending the guest, but in order to emphasise one's special disposition (Karyagin, 1994). Ignoring protocol rules by Soviet leaders, in most cases, had a negative impact on their reputation, and as a result - on the image of the state. Ceremonial implies the presence of the main participants (players) of communication and spectators, who in turn can take an active and passive position in relation to the ceremonial action. The passive position is limited to observing what is happening, the active position is limited to analysing it. Thus, the performance of L.V. Beethoven's "Ode to Joy" at a concert of Ukrainian music during the inaugural celebrations of V.A. Yushchenko was perceived by analysts as Ukraine's choice of a European course of development ("Ode to Joy" - is the anthem of the European Union).

If the participants of the ceremony are classified as "players", "spectators" and "analysts", then "players" and "analysts" prevail in diplomatic ceremonies. Thus, the diplomatic ceremonial imposes strict requirements for the implementation of the rules of etiquette, the observance of which also determines the nature of relations between states. As D. Wood and J. Serre (2016) note in their study: "Diplomacy is the art of resolving international differences by peaceful means. Diplomacy is also a technique and skill that harmoniously affect international relations and obey certain rules and customs. Diplomatic activity has always had a pronounced ritual character." Diplomats and official representatives of states, governments and international organisations use traditional methods to solve foreign policy problems. Traditional forms of diplomatic activity are conservative. But conservatism is indicative of a "school", i.e. an established system of theoretical knowledge and practical skills that has evolved throughout the history of international relations. The tasks of real politics make their own adjustments to the old ceremonial forms and create new ones (often not always productive, for example, "meetings without ties").

"In essence," wrote J. Cambon, "not everything is already so meaningless in these solemn trifles. Foreign agents are representatives of something higher than themselves. The honours paid to them are addressed to the head of the state, whose representatives they are. <..> The Protocol does not know the victorious peoples and the defeated peoples. He even prescribes mutual respect to warring nations, regardless of the ratio of their forces. It is, of course, only a formality that does not essentially prejudge anything yet, but ... this formality shows respect for the dignity and independence of 
weak nations, which is no small thing" (Wood \& Serre, 2016). The Protocol is intended to "protect" in practice the principles of sovereignty, equality and territorial integrity of states. No one denies the existence of actors in world politics, but unlike the domestic political system of states, where there is a political hierarchy in international relations, the principles of equality apply. The greater the upheavals in the political life of the state, the more drastic the changes in the forms and conditions of life and the further away from the present generations are the past epochs. "Modern society easily and recklessly renounces the recent laws of life, with contempt and mockery waves its hand at the former way of life and deliberately breaks any connection with the native past." These words by E.N. Opochinin (1909) are surprisingly consonant with today's time. Meanwhile, in order to "go forward more cautiously and more correctly, it is good sometimes to remember where you are coming from." In the 1990s, the power structures in the post-Soviet space abandoned Soviet ceremonials. At the same time, new forms of their implementation have not been created. It is impossible to cancel the ceremony overnight or change its structure. For a hundred years of the existence of the ritual of awarding Nobel laureates, there was only one change in it - the King of Sweden moved from the hall to the stage. Observance of traditions is a tribute to previous generations, their thoughts and ideals.

\section{Conclusions}

The sociological direction considers culture as a system of symbols shared by a group of people and transmitted by it to the next generations; as a system of beliefs, values and norms of behaviour that organise social ties, and, finally, as an organisation of objects and phenomena based on symbols, beliefs, language, customs. A ceremonial is a kind of cultural message of one social group of people. The basic idea of behaviour, the inner meaning of secular ceremonial is laid down in church rituals, and external forms of conduct can be borrowed from the traditions of everyday secular life. The development of social life, which, although varied and complex, is characterised by the repetition of similar situations, has led to the emergence of a certain order of behaviour in society - custom. When a form of behaviour begins to be controlled by legal acts, it becomes a ceremonial designed to maintain a harmonious connection between generations within a particular people, social group, historical community.

A ceremonial is an event in the life of society that has a symbolic meaning. The norms of ceremonial reflect not only ideology, but also the social psychology of society, without an adequate interpretation of which it is impossible to correctly understand the behaviour of statesmen in specific situations related to their official status. The diplomatic protocol, being a part of the state ceremonial culture, is an illustration of the spiritual, moral and political state of society. In every culture, every society, there is a kind of code of communication rules that permeates almost all types of both official and unofficial interaction. In imperial states with developed vertical power, the issue of structuring public life, of which ceremonial culture was a part, was particularly acute. During the study, it was found that the ceremonial plays a crucial role in diplomatic relations. Essentially, being a formality, the ceremonial protocol protects the principles of sovereignty, equality and territorial integrity of states. Violation of the protocol, in turn, may demonstrate diplomats' negative intentions or their insufficient level of knowledge of the etiquette rules. Thus, for the first time, such a term as "diplomatic counterculture" is introduced into circulation.

In this study, art is considered for the first time from the point of view of the communicative factor of diplomatic ceremonial. It has been found that art can serve as a way of showing respect and exchanging cultural values, significantly influencing diplomatic relations. Thus, architecture, music, painting can have a communicative status within the ceremonial, and the demonstration of works of art to foreign diplomats can positively influence their attitude to a particular subject of discussion. Visual means of communication include heraldic signs, including emblems, coats of arms, uniforms, etc. One of the ways to show hospitality in diplomacy is the gift exchange ceremony, where works of art play a special role.

\section{References}

Bayburin, A. K., \& Toporkov, A. L. (1990). At the origin of etiquette. Ethnographic essays. Leningrad: Nauka.

Chichagov, M. I. (1999). Shamil in the Caucasus and in Russia. Moscow: Tonar.

Chopin, O. (2018). The diplomat, the soldier, and the spy: Toward a new taxonomy in international relations. In O. Schmitt (Ed.), Raymond Aron and International Relations (pp. 179-194). London: Routledge. https://doi.org/10.4324/9781315620114-11

Churchill, W. (2020). World War II. Moscow: Alpina Non-Fikshn.

Crow, J. (2018). The gesture of drawing in Antoine De Saint-Exupery's The Little Prince. In A. Sioli, \& Y. Jung (Eds.), Reading Architecture (pp. 105-113). London: Routledge. https://doi.org/10.4324/9781315402901-11

Dalelbekkyzy, A., Bisengali, Z.-G., Toleubayeva, A., Zhanat, A., \& Baitanasova, K. M. (2019). National code: Metaphysics and unity of historical consciousness. Analele Universitatii din Craiova - Seria Istorie, 35(1), $105-118$. 
Donogono-Korkmas, M. (1990). Portraits of Shamil in Europe. Makhachkala: Nauka.

FPA RF (Foreign Policy Archive of Russian Federation) F. 057. Op. 15. P. 112. D. 2.

FPA RF. F. 057. Op. 19. P. 113. D. 1.

FPA RF. F. 57. Op. 46. P. 279. D. 52.

FPA RF. F. 57. Op. 78. P. 623. D. 14.

Karyagin, V. V. (1994). Diplomatic life behind the scenes and on stage. Moscow: Mezhdunarodnyye otnosheniya.

Krichevsky, R. L. (1998). If you are a leader. Moscow: Delo.

Krokhina, I. M., \& Krupenin, A. L. (Eds.). (1997). All about etiquette. Rostov-on-Don: Phoenix: Feniks.

Kutsyi, O. (2021). Theoretical basis of the concept "organizational culture": analytical and synthetic research. Social and Legal Studios, 2, 194-201. https://doi.org/10.32518/2617-4162-2021-2-194-201

Milyukov, P. N. (1993). Essays on the history of Russian culture. Moscow: Progres.

Motliakh, O. (2021). Moral and ethical principles in the international relations. Law Journal of the National Academy of Internal Affairs, 11(1), 7-14. https://doi.org/10.33270/04212101.7

Opochinin, E. N. (Ed.). (1909). Gogol time: Original drawings by count Ya. P. de Balmain. Moscow: K. A. Fisher.

Orlov, Y. (2021). Thermodynamic processes in the social system. Scientific Journal of the National Academy of Internal Affairs, 118(1), 50-57. https://doi.org/10.33270/01211181.50

Ryspayeva, D., Zhukenova, A., Ismagulova, A., Kulakhmetova, M., \& Fadeeva, L. (2021). National and cultural variation of the concept. Astra Salvensis, 2021, 13-25.

Sabadash, J., Petrova, I., Oriekhova, S., Polishchuk, L., Haidukevych, K., \& Otrishko, M. (2020). Historical, cultural and tourist monuments as a factor in the development of territories. International Journal of Advanced Research in Engineering and Technology, 11(6), 485-493.

Saifnazarov, I. S. (2019). Innovative methods of forming spiritual immunity of youth (on an example of Tashkent State University of economics experience). Astra Salvensis, 1, 355-362.

Serdali, B. K., Sadykov, S., Tuyakbayev, G. A., Ashirbekova, G. S., \& Zhaxylykbaeva, R. S. (2017). National identity in the print media of Kazakhstan in the late Soviet period. Global Media Journal, Canadian Edition, 10(1), $134-148$.

Sukhodrev, V. M. (2008). My tongue is my friend. Moscow: Tonchu.

Sukhonos, V. V., Kane, S., \& Wilkinson, G. (2021). Social basis of state power in the conditions of a Latin American-type state. Legal Horizons, 14(2), 91-97.

Turysbek, R. S., Sarekenova, K. K., Baitanasova, K. M., Myrzakhmetov, A. A., \& Aimukhambet, Z. A. (2021). The role of historical figures and legend motifs in the modern prose structure in expressing the idea of statehood. Astra Salvensis, 2021, 383-393.

Volkova, P., Luginina, A., Saenko, N., \& Samusenkov, V. (2020). Virtual reality: Pro et contra. Journal of Social Studies Education Research, 11(4), 190-203.

Wood, D., \& Serre, J. (2016). Diplomatic ceremony and protocol. Moscow: Mezhdunarodnyye otnosheniya.

Yessenbayeva, A. M., Yelikbayev, B. K., Abdrahman, G. K., Makulova, L. T., \& Serdali, B. K. (2020). Investigating the communicative functions of interrogative sentences in dialogue texts. Media Watch, 11(3), 488-501.

Zakharova, O. Y. (2015). Business and civil etiquette. Moscow: Tsentrpoligraf.

\section{Copyrights}

Copyright for this article is retained by the author(s), with first publication rights granted to the journal.

This is an open-access article distributed under the terms and conditions of the Creative Commons Attribution license which permits unrestricted use, distribution, and reproduction in any medium, provided the original work is properly cited. 